Vol. 2, No. 2, December 2021

DOI: https://doi.org/10.18196/ijiep.v2i2.12731

\title{
Islamic Boarding School Response to the Impact of COVID-19 in Maintaining the Pesantren Values
}

\author{
Ahmad Salim*, Ibnu Ubay Dillah, Ika Tri Susilowati \\ Universitas Alma Ata, Indonesia \\ *Corresponding email: ahmadsalim0305@almaata.ac.id
}

ARTICLE INFO

Article History

Received : 13/09/2021

Revised : 10/11/2021

Accepted: 07/10/2021

Keywords

Learning, Islamic

Boarding School,

COVID-19 Pandemic,

Pesantren, Values

\begin{abstract}
The COVID-19 affects all aspects of life, including Islamic boarding schools or pesantren. These institutions are having difficulty conducting online learning activities because they are not familiar with this method. This study aims to reveal Islamic boarding schools' response toward the impact of COVID-19 in maintaining pesantren values at Pesantren Miftahul Ulum, Subang, West Java. The study utilized the descriptive qualitative method. The respondents of this study were teachers (ustadz), students (santri), and leaders (kyai). The data were collected through observation, interviews, documentation, and online searching. The triangulation was employed as the data validity technique, and the data analysis technique used data reduction, data display, data verification, and conclusion. The result showed that pesantren responses in maintaining the pesantren values due to the impact of COVID-19 such as limiting the learning time in class, limiting the santri's capacity per classroom, and limiting ustadz interaction with santri in the classroom. The learning process during the pandemic was carried out face-to-face and strictly adhered to the health protocol. The learning methods employed were sorogan, bandongan, and kempekan. Pesantren also internalizes morals to the students to guarantee the value.
\end{abstract}

This is an open-access article under the CC BY-SA license.

\section{Citation:}

Salim, A., Dillah, I. U. \& Susilowati, I. T. (2021). Islamic boarding school response to the impact of COVID-19 in maintaining the pesantren values. International Journal of Islamic Educational Psychology, 2(2), 177-190. DOI: https://doi.org/10.18196/ijiep.v2i2.12731 
Salim, Dillah \& Susilowati | Islamic Boarding School Response to the Impact of COVID-19 in Maintaining the Pesantren Values

\section{INTRODUCTION}

The COVID-19 pandemic restricts many sectors in human life, especially in Indonesia, which is currently experiencing online-based learning. This method is done outside the classroom through the existing communication media platforms. The COVID-19 affects formal and religious-based education, such as Islamic Boarding School, based on Islamic religion (Syah, 2020). It is easier for Islamic Boarding School, commonly known as pesantren, to shape the students' character because they use a dormitory system to implement Islamic values in everyday life.

During the COVID-19 pandemic, pesantren classifies their learning models into three: 1) online learning (Kahfi \& Kasanova, 2020), 2) independent learning or with parental guidance (Murtadlo, 2020), and 3) face-to-face learning at pesantren (Murtadlo, 2020). In response to the rapid social changes in society and to maintain the values of pesantren, the Ministry of Religious Affairs provides several conditions for those which conduct a face-to-face learning activity such as the environment of pesantren, and teachers and students who need to be safe from COVID-19 (Suud, et al., 2020), and the enforcement of strict health protocols. Unfortunately, pesantren faced a problem to carry out the online-based learning activities because students were not able to receive any moral value provided by their kyai (the leader of pesantren) (Syafe'i, 2017).

Based on the rules issued by the government, Pesantren Miftahul' Ulum continues to apply face-to-face learning activities, done due to its effectiveness. Furthermore, pesantren is the most appropriate place to deal with the pandemic condition. Although it is different from the goal of the health quarantine, the students stated that those who stay at pesantren are safer from exposure to COVID-19.

Studies related to the learning activities carried out at pesantren have been conducted by many researchers, such as Kholili (2021), who discussed the challenges for pesantren in the revolution era of society 5.0. Pesantren must be aware of the challenges to maintain its existence by implementing morals, a technology-based pesantren system, and digital literacy and digital ethics (Kholili, 2021). Mustakim (2021) discussed learning strategies at pesantren during the COVID-19 pandemic (Mustakim, 2021). Zamhari and Rahmayanti (2021) discussed pesantren's response and negotiation in maintaining its values during the pandemic. Blended learning between the offline learning system for some students who live at pesantren and the online learning system for those who live at home was regarded as less effective in teaching the values of pesantren (Zamhari \& Rahmayanti, 2021). Hannan et al. (2020) discussed the dynamics of social roles carried out by pesantren in response to the COVID-19 in Madura (Hannan et al., 2020).

Based on the reality above, it is necessary to conduct this study. It aims to analyze how Pesantren Miftahul 'Ulum responds to the rapid change and maintenance of 
the community and assure its values during the pandemic. The writers also revealed that pesantren tends to maintain its identities built for a long time, such as bandongan (learning method where santri get to learn in a group and are allowed to discuss the subject matters), sorogan (individual learning where santri ask the kyai to teach them about materials they want to know), and kempekan (learning method to practice how to read Al-Qur-an). It becomes the main evident that pesantren can survive and keep up with several developments despite the social change due to COVID-19 or other aspects.

\section{Response of Pesantren to the impact of COVID-19}

Pesantren is an educational institution that typically originated from the archipelago. These Islamic educational institutions continue to develop with numerous variants. Some are traditional, modern, or mixed, but they do not leave their roots by emphasizing religious education and morality (Kholidi, 2016). By getting to know more about the types of pesantren in Indonesia, we will know the advantages and characteristics of each type of pesantren. Here are some types of pesantren in Indonesia: 1) traditional pesantren, 2) modern pesantren, and 3) mixed of both.

Pesantren is a traditional Islamic education dormitory where santri live and study the science of religion under a teacher who is better known as a kyai. In Indonesia, a pesantren must have a dormitory for its santri, whether for males or females. Dormitories and pesantren cannot be separated because they have merged, so up to this time, it is tricky to find a pesantren without a dormitory. At pesantren, a kyai teaches his santri about religious knowledge taken from Arabic books written by 'ulama who lived in the medieval era (Izzah \& Hanip, 2018). The concept of barakah or commonly called a blessing is also closely related to pesantren. Santri who are serious about studying religious knowledge with their kyai will receive blessings. Pesantren and books written in Arabic are as close as pesantren with dormitories and kyai and santri. So far, Arabic books are still intensively used in this modern era.

The response of pesantren to the impact of the COVID-19 pandemic can be seen from the type of understanding adopted by the pesantren, divided into two types: 1) conservative Islamic understanding and 2) non-conservative Islamic understanding. Pesantren that adhere to conservative Islam tend to oppose the government's policies because death belongs only to Allah SWT and invites all people to keep carrying out worship and social activities before the pandemic. Meanwhile, the non-conservative one is more dynamic and moderate in responding to the impact of COVID-19. Pesantren has two agendas during the pandemic. The first is Structural-Medical, where pesantren incorporate health protocols into all pesantren's activities. The second is Cultural-Religious, where the involvement of pesantren amid people's lives to educate the importance of taking care of themselves, their families, and the community to protect them from the COVID-19 (Hannan et al., 2020). 
Salim, Dillah \& Susilowati | Islamic Boarding School Response to the Impact of COVID-19 in Maintaining the Pesantren Values

\section{Pesantren Values; Learning and moral internalization}

Pesantren only has two learning methods, sorogan and bandongan, because they have been carried out for a long time. The sorogan method requires patience, skills, obedience, and discipline for both the ustadz and santri because this method is carried out individually between the two parties. The bandongan method is the primary learning method utilized at pesantren. The ustadz reads, translates, explains, and reviews several Arabic books to a group of santri. Meanwhile, the sorogan system is the most effective learning method at pesantren as the initial stage of those who aspire to become 'alim (Dhofier, 2019).

Pesantren is an Islamic educational institution in Indonesia that has long been consistent in providing character education to all its students with comprehensive learning as proof. Character education has three components: moral knowledge, moral feelings, and moral actions. Moral knowledge is the most important part of character education concerning moral awareness, moral values, moral thinking, decision-making, and personal knowledge (Salim, 2012).

In making decisions, individuals can think about how to act through moral problems by employing reflective decision-making skills. What are the consequences of making moral decisions that have been taught even to preschool children? Meanwhile, personal knowledge is a type of moral knowledge that is tricky to obtain, but it is necessary for character development (Julaeha, 2019). This component discusses a person's emotional nature, which is often overlooked in moral education even though it is essential. A person possesses six characteristics: conscience, self-esteem, empathy, loving, kindness, self-control, and humility (Julaeha, 2019).

If one has moral intelligence and emotional qualities, they might do what they want to know and what they think is true. Moral action is found in several aspects, such as competence, desire, and habits. In great situations, moral action gains benefits from the habit. A person often does a good deed because of habitual encouragement. As part of moral education, every child requires many opportunities to develop good habits and a lot of practice when it comes to being a good person (Julaeha, 2019). Character education is divided into four types: 1) religious value-based character education, 2) cultural value-based character education, 3) environmental-based character education and 4) self-potentialbased character education (Chandra, 2020).

\section{METHODS}

This research was conducted at the Pesantren Miftahul' Ulum online and offline due to the COVID-19 pandemic. It was carried out from March 2021 to April 2021. The subjects of this research consisted of Pesantren Miftahul' Ulum's ustadz, santri, and the board of directors. The researchers interviewed twelve (12) ustadz, fifty (50) santri comprised of twenty-five (25) male santri and twenty-five (25) female santri, and one (1) leader of pesantren (kyai). This number was decided based on the collection technique used and the needs of the researcher. 
Salim, Dillah \& Susilowati | Islamic Boarding School Response to the Impact of COVID-19 in Maintaining the Pesantren Values

The data collection techniques used were observation, interviews, documentation, and online data searching. For observation, the researchers conducted a direct review of the research site to validate the data obtained. The researchers conducted interviews with ustadz, santri, and the leader of the Pesantren Miftahul' Ulum as research subjects. Documentation was to claim that the data was obtained as appropriate. Online data searches were also done due to the COVID-19 pandemic, so the researchers collected the data needed on social media or the Pesantren Miftahul' Ulum's website.

Two types of triangulation were utilized as the data validity techniques, triangulation of data sources and triangulation of methods. To get the truth of the data, the data that had been obtained were then compared to the other data. For example, the data that the researchers got from the Pesantren Miftahul' Ulum's ustadz were compared to the data obtained from the Pesantren Miftahul' Ulum's santri, and vice versa (Hadi, 2017). Various data collection methods were used to obtain the same data and as an effort to prove that the previously obtained data was truly valid. Therefore, the researchers used the triangulation method by digging up the data obtained and then looking for other data by a second party, third party, and using different methods to avoid subjective data (Rijali, 2018).

Data analysis techniques that researchers used were: 1) data reduction, 2) data display, and 3) data verification/conclusion. For data reduction, the researcher summarizes field notes so that they become more focused. The researchers made a graph or image to display the data so that the field data could be easily read. For data verification/concluding, the researchers took the objectivity, then compared the results to the theory and revealed the contents of the results to answer all the problem formulations that had been determined (Rukajat, 2018).

\section{RESULTS}

Miftahul' Ulum Islamic Boarding School implements all formal and non-formal activities carried out face-to-face by following the rules of social distancing, wearing masks, and washing hands. Before the pandemic, this pesantren has been imposing a policy on environmental hygiene to create a healthy environment shown by the healthy menu, the activities of the residents such as sports and exercise, and ro' an (cleaning the dormitory) together every week.

Based on the interview, the head of the COVID-19 task force at the Islamic boarding school stated no positive cases in this institution. So far, no positive cases of COVID-19 found at Miftahul' Ulum Islamic Boarding School, Subang, West Java were found. In addition to obeying the strict health protocols, the residents were also asked to always pray to Allah, the owner of this disease, and continue to make an effort so that the residents will be able to stay safe from the COVID-19 until this pandemic ends. 
Salim, Dillah \& Susilowati | Islamic Boarding School Response to the Impact of COVID-19 in Maintaining the Pesantren Values

The pesantren's policy in maintaining face-to-face activities is based on the efforts of both the pesantren and the Regional Government, which also gives its support to pesantren in Subang, West Java. All activities were still the same before the pandemic. The only exception was that the learning activities during the formal education and Qur'an recital at pesantren were conducted by following the health protocols as follows: 1) limiting the time of the learning process, 2) limiting the number of the students in the classroom, and 3) maintaining physical distancing in all activities.

The interview results showed that more than $75 \%$ of respondents said that faceto-face learning was needed to maintain the values and characteristics of the pesantren culture, such as the bandongan, sorogan and kempekan methods. Some of the methods that characterize this pesantren are still conducted face-to-face by following the health protocols.

Miftahul' Ulum Islamic Boarding School uses books as teaching materials because students are taught to learn Arabic by interpreting, giving harakat, and understanding its contents which is more important than using other teaching materials. Moreover, students are living in Islamic boarding schools with a solid Islamic culture.

\section{DISCUSSION}

\section{Miftahul Ulum Pesantren's response to Impact of COVID-19}

Strict health protocols are implemented to avoid the spread of COVID-19 in the Pesantren Miftahul' Ulum environment as stipulated in Government Regulation Number 21 of 2020 concerning Large-Scale Social Restrictions in the Context of Accelerating the Handling of COVID-19 issued by the President of the Republic of Indonesia. Pesantren residents are also asked to always pray to Allah SWT, the mighty creator of COVID-19, and continue to strive so that pesantren residents remain safe from COVID-19 until the pandemic ends. Pesantren Miftahul' Ulum's COVID-19 Task Force will enforce an independent isolation policy in the pesantren environment if there are positive cases of COVID-19 among pesantren residents policy has certainly been recommended by the government's COVID19 task force center. The isolation room provided at the pesantren fulfills the regulation issued by The Ministry of Religious Affairs of The Republic of Indonesia to avoid the spread of COVID-19 in the pesantren environment.

The caregiver of the Pesantren Miftahul' Ulum did not enforce an online learning policy in the COVID-19 pandemic not because the technology was insufficient but the caregiver wanted to continue face-to-face learning activity because he tried to maintain the characteristics of pesantren. According to the caregiver, if the pesantren implemented learning online, the role of pesantren is not involved in shaping the character of santri to become santri who have good morals in society. Therefore, pesantren is a means to shape better human character according to Islamic teachings. During the COVID-19 pandemic, pesantren should strive to maintain face-to-face learning, with some effort to ensure that the learning 
Salim, Dillah \& Susilowati | Islamic Boarding School Response to the Impact of COVID-19 in Maintaining the Pesantren Values

activities do not become a place where COVID-19 spread. Therefore, pesantren policies must be adjusted to the COVID-19 health protocol. Pesantren should jointly disseminate information to the surrounding communities to comply with government policies so that the COVID-19 pandemic can be resolved and end soon.

Due to the pandemic, some facilities need to be provided to implement health protocols appropriately. This situation impacts pesantren, and they are required to have the appropriate facilities so that the residents of Islamic schools are wellfacilitated in complying with health protocols. These facilities are: 1) a place to wash hands with running water, 2) an empty room to be used at any time if there are pesantren residents who are exposed to COVID-19, and 3) a disinfectant liquid sprayer to sterilize a place that has been used to avoid contamination and the spread of COVID-19. The lack of pesantren facilities in preventing the spread of COVID-19 does not mean that pesantren is not ready to maintain its existence during the COVID-19 pandemic (Zamhari \& Rahmayanti, 2021). However, the funds available to pesantren have been fully used to construct mosques before the COVID19 pandemic hit Indonesia. The assistance received from the Subang Regency Government is not sufficient for long-term sustainability with productive pesantren activities every day.

All formal and non-formal activities are carried out face-to-face by complying with social distancing rules, wearing masks, and washing hands. Before the COVID-19 pandemic in Indonesia, Pesantren Miftahul' Ulum, Subang, West Java, had imposed a policy on environmental hygiene to create a healthy environment seen from selecting healthy food menus for the pesantren residents. Additionally, pesantren's residents have activities like doing sports and ro'an (cleaning the dormitory) together every week. Maintaining a clean environment, healthy eating patterns, and increasing body immunity are recommendations from the Ministry of Health of The Republic of Indonesia to prevent the spread of COVID19 in the surrounding environment.

The policy of pesantren to maintain face-to-face activities is based on the efforts of the Pesantren Miftahul' Ulum and the Regional Government, which also helps pesantren in the Subang, West Java to continue face-to-face activities. All activities are still the same as before the COVID-19 pandemic. However, there are some adjustments related to learning activities in classes and reading the Qur'an at pesantren. The adjustments made are 1) limiting the time for the learning process in the classroom, 2) limiting the number of santri in the classroom during the learning process, and 3) keeping a safe distance in all pesantren activities during the COVID-19 pandemic.

\section{Maintaining of values at Miftahul 'Ulum Pesantren}

The learning atmosphere at the Pesantren Miftahul' Ulum today is undoubtedly different from the previous years. There are adjustments made to the learning process. This adjustment occurs due to the COVID-19 pandemic that is still 
Salim, Dillah \& Susilowati | Islamic Boarding School Response to the Impact of COVID-19 in Maintaining the Pesantren Values

engulfing Indonesia and the world. Before the COVID-19 pandemic, the students were active in the class during the learning process. The distance between the ustadz and the santri in the classroom was not far apart. Moreover, the ustadz and the santri could recognize each other because nothing covered part of their face. Also, the moral learning taught by the ustadz to the santri in the class is optimal, shown by the santri who always kiss the hand of the ustadz when they want to leave the class.

The situation is different now, where learning is adjusted to the COVID-19 health protocols. Ustadz and santri must wear masks, keep a safe distance and sterilize hands with hand sanitizers. The adjustments make the learning atmosphere in the classroom limited, both in terms of interactions built by ustadz and the learning activities. The learning methods ustadz at the Pesantren Miftahul' Ulum in the COVID-19 pandemic were bandongan (ma'nani), sorogan, and reading the Qur'an using the kempekan method. The learning method is implemented based on adjustments to the COVID-19 health protocols, which requires keeping a safe distance during the learning activities in pesantren. There are only two learning methods in Islamic boarding schools, called sorogan and bandongan, which have long been practiced by Islamic boarding schools in Indonesia (Dhofier, 2019).

a. Bandongan or Ma'nani Method

Bandongan or ma'nani is a teaching method where the ustadz reads, interprets, gives harakat, and explains the meaning of the verses or sentences read. Then, the santri write, give syakal, and pay attention to what is conveyed by the ustadz in class (Wahyono, 2019). The bandongan method is carried out when studying the kitab kuning. For these learning activities, four classes are provided: 1) first grade, which is attended by new santri, 2) second grade, which is attended by the first-grade santri who pass the exam and continue to second grade, 3) third grade, which is attended by second-grade santri who pass the exam and continue to third grade and 4) fourth grade, which is filled by santri who enter the Madrasah Tsanawiyah level at their formal school and continue to the Madrasah Aliyah level at pesantren so that they go straight to fourth grade. Implementing the bandongan method at the Pesantren Miftahul' Ulum is similar to that of other pesantren. Ustadz are the sources of knowledge in the classroom, and santri focus on giving meaning, giving syakal, and comprehending when the ustadz reads, provides meaning and explains the contents of the sentence to santri. Ma'nani (giving meaning to the book) is commonly used by pesantren around the Pantura area of West Java. However, it is different in pronunciation but remains the same in meaning, so ma'nani is generally bandongan.

b. Sorogan Method

The Sorogan method comes from the Javanese term sorog, which means to thrust, where santri brings books that have been given meaning and studied and then reads them aloud to their ustadz independently (Wahyono, 2019). The sorogan method is carried out after the fajr prayer in the congregation. In this 
method, the santri are also divided into three classes as in the bandongan method. Implementing the sorogan method at the Pesantren Miftahul' Ulum is that the santri become the center of knowledge because the santri have to show the results of their independent learning directly to the ustadz. Independent learning done by santri is by interpreting, giving syakal for a chapter or sentence in the kitab kuning. Later the santri are required to present the book's meaning to train santri to read the kitab kuning correctly and adequately.

c. Read the Qur'an with the Kempekan Method

The kempekan method applied at the Pesantren Miftahul' Ulum was carried out during the Al-Qur'an learning after the Maghrib prayer in the congregation. There are three classes for kempekan: 1) Juz' Amma class filled by new santri who are not yet fluent in reading the Qur'an, 2) Al-Qur' an class is filled by santri who are fluent in reading the Qur'an, and 3) Al-Qur'an memorization class is filled by santri who have completed the Qur'an Bin Nadzri (reading the Qur' an with a book) who is guided directly by the caregiver. This method follows the teaching method of reading the Qur'an applied by Pesantren Kempek Cirebon, West Java, and this method is one of the most famous methods used by pesantren in Indonesia.

Pesantren Miftahul' Ulum certainly has to learn to cope with obstacles in the COVID-19 pandemic. These obstacles are the limited teaching and learning activities in pesantren. The pesantren also consider external and internal factors to carry out the learning process (Muspawi \& Vahlepi, 2021). The essential thing in an educational institution is the ongoing teaching and learning activities that need to be fulfilled. Therefore, if the teaching and learning process is limited, the teaching and learning process cannot take place optimally.

The external factors come from outside the pesantren, and they need to be considered carefully to maintain feasible learning activity during the pandemic. This pandemic changes old learning patterns into new learning patterns and forces people to follow health protocols (Dwivedi, et al., 2020). The policy taken by the Pesantren Miftahul' Ulum is to limit teaching and learning activities such as 1) limiting the learning time, 2) limiting the number of santri in the classroom, and 3) limiting ustadz communication during the learning process. The pesantren took this as a form of prevention to spread COVID-19 in the Pesantren Miftahul' Ulum Subang, West Java. These limitations are an implementation of the policy issued by The Ministry of Religious Affairs of The Republic of Indonesia regarding learning in pesantren that are ready to carry out face-to-face learning.

Internal factors that optimize the teaching and learning process are limited due to policies from the central government to implement strict health protocols, maintain distance, wear masks, and sterilize hands using hand sanitizers or other antiseptics. Pesantren's residents should be properly protected from the spread of COVID-19 (Herdayati et al., 2021). Thus, they must comply with 
Salim, Dillah \& Susilowati | Islamic Boarding School Response to the Impact of COVID-19 in Maintaining the Pesantren Values

pesantren's new policy so that all residents are safe during the teaching and learning process.

\section{Internalization of Moral Values at Miftahul' Ulum Pesantren during COVID-19 Pandemic}

Based on the data from interviews and field observations, it can be seen that in the Pesantren Miftahul' Ulum environment, character education and moral education have the same meaning. They are considered a trait embedded in each individual's soul and encourage people to act without thinking. Moral education in Islam is essential to teach, following a hadith saying that the perfection of a person's faith depends on his morals. In the pesantren's environment, the values of character education (Baharun, 2017) that are taught include all human activities in all areas of life (Putro \& Suryono, 2019).

According to one of the ustadz at Pesantren Miftahul' Ulum, in addition to being taught about the Qur'an and Al-Hadith and the noble values of Pancasila, he also taught several books containing valuable materials (Khafidah et al., 2020). The delivery of the material has certainly been adapted to the developmental ability of santri's thinking. The education system implemented at the Pesantren Miftahul' Ulum is correct, proven by the santri, who have good personalities and characters. In developing the morals of the santri, it is certainly not easy. Everything needs clear processes and stages. A good personality must be formed directly by the pesantren environment.

The pesantren has a Kyai figure who is highly respected by the santri and the surrounding communities because of his scientific abilities and charisma (Rahawarin, 2019; Melani, 2021). In Pesantren Miftahul 'Ulum environment, character education will be taught directly by a Kyai by always practicing moral values in everyday life, such as always advising students after Maghrib prayers in the congregation. Then this was also done by the ustadz, who always set an example to come to the mosque on time during the five daily prayers, always dress neatly, and speak good words in communicating with others. This Kyai will undoubtedly have a significant impact on character education for santri.

More than $80 \%$ of respondents stated that the internalization of values/characters was carried out not only by learning that emphasized the cognitive understanding of students at specific values. The habituation of values in students' daily activities is a form of internalized values that effectively instill these values in students' lives. The application of punishment for students who violate the rules of the pesantren is also an effort to internalize specific values (Suud et al., 2020).

The Kyai's role as a role model in daily activities in the pesantren effectively facilitates the internalization of student character values. Kyai's daily activities become a real example for students carrying out almost all their daily worship and social activities. This reality follows what Julaeha (2019) conveyed that the internalization of values to students requires several ways, namely the delivery 
Salim, Dillah \& Susilowati | Islamic Boarding School Response to the Impact of COVID-19 in Maintaining the Pesantren Values

of information, appreciation, and practice of values in students' daily lives (Lickona, 1991).

\section{CONCLUSIONS}

Miftahul Ulum pesantren's response to the impact of COVID-19 is to organize a face-to-face learning process by paying attention to several aspects; adjusting to the COVID-19 health protocol as follows: 1) limiting learning time in class, 2) limiting the number of students in the class and 3) limiting the interaction of ustadz with students in the classroom. Another policy is self-isolation in a special room in the pesantren environment if residents of the pesantren Miftahul' Ulum are exposed to people who are tested positive of COVID-19. To maintain the noble values, Pesantren Miftahul Ulum continues to implement the learning methods characteristic of the pesantren, called the bandongan, sorogan, and kempekan methods. These methods can be effectively implemented because they are carried out face-to-face while still complying with health protocols. This pesantren also internalizes noble values to its students by teaching them, strengthening the values in students' personalities, and applying them in students' lives. Kyai plays an important role in internalizing values in students' lives because Kyai acts as a role model for actualizing values.

\section{REFERENCES}

Baharun, H. (2017). Total moral quality: A new approach for character education in pesantren. Ulumuna, 21(1), 57-80. https://doi.org/10.20414/ujis.v21i1.1167

Chandra, P. (2020). Internalisasi nilai-nilai karakter dalam tradisi pondok pesantren. Nuansa : Jurnal Studi Islam dan Kemasyarakatan, 12(2), 64-80. https:// doi.org/10.29300/nuansa.v12i2.2760

Dhofier, Z. (2019). Tradisi pesantren studi pandang hidup kyai dan visinya mengenai masa depan Indonesia. Jakarta: LP3ES.

Dwivedi, Y. K., Hughes, D. L., Coombs, C., Constantiou, I., Duan, Y., Edwards, J. S., Gubta, B., Lal, B., Misra, S., Prashant, P., Raman, R., Rana, N. P., Sharma, S. K., \& Upadhyay, N. (2020). Impact of COVID-19 pandemic on information management research and practice: Transforming education, work and life. International Journal of Information Management, 55, 102211. https://doi.org/10.1016/j.ijinfomgt.2020.102211

Hadi, S. (2017). Pemeriksaan keabsahan data penelitian kualitatif pada skripsi. $\begin{array}{llll}\text { Jurnal Ilmu Pendidikan, } & \text { 22(1), } & 109874 .\end{array}$ https://doi.org/10.17977/jip.v22i1.8721 
Salim, Dillah \& Susilowati | Islamic Boarding School Response to the Impact of COVID-19 in Maintaining the Pesantren Values

Hannan, Abd; Azizah, Siti; Atiya, H. (2020). Dinamika pesantren dalam merespons pandemi COVID-19 di Madura. DINIKA: Academic Journal of Islamic Studiies, 2(4), 213-242. https://doi.org/10.36548/jismac.2020.4

Herdayati, M., Besral, B., \& Karniastuti, J. (2021). Knowledge, attitude, and practice regarding COVID-19 among residents of pesantren. Kesmas: Jurnal Kesehatan Masyarakat Nasional (National Public Health Journal). http:/ / dx.doi.org/10.21109/kesmas.v0i0.5174

Izzah, L., \& Hanip, M. (2018). Implementasi pendidikan akhlak dalam pembentukan akhlak keseharian santri. LITERASI (Jurnal Ilmu Pendidikan), 9(1), 63-76. https:// doi.org/10.21927/literasi.2018.9(1).63-76

Julaeha, S. (2019). Problematika kurikulum dan pembelajaran pendidikan

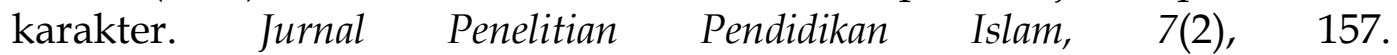
https:// doi.org/10.36667/jppi.v7i2.367

Kahfi, S., \& Kasanova, R. (2020). Manajemen pondok pesantren di masa pandemi COVID-19. Pendekar: Jurnal Pendidikan Berkarakter, 3(1), 26-30. https:// doi.org/10.31764/pendekar.v3i1.2827

Khafidah, W., Wildanizar, W., Tabrani, Z. A., Nurhayati, N., \& Raden, Z. (2020). The application of wahdah method in memorizing the qur'an for students of SMPN 1 Unggul Sukamakmur. International Journal of Islamic Educational Psychology, 1(1), 37-49. https://doi.org/10.18196/ijiep.1104

Kholidi, I. (2016). Memahami hakikat pondok pesantren. Mahad.ipmafa.ac.id. https://mahad.ipmafa.ac.id/2016/01/memahami-hakikat-pondokpesantren.html

Kholili, Y. (2021). Challenges for Pesantren in the revolution era of society 5.0. AMCA Journal of Religion and Society, 1(1), 8-12. https://doi.org/10.51773/ajrs.v1i1.33

Lickona, T. (1991). Educating for character. New York: Bantam.

M. Suud, F., Gaffar, A., Rouzi, K., \& Chaer, M. (2020). The role of islamic counselling in pandemic COVID 19: A conceptual study for developing positive emotion of parents and children. KONSELING RELIGI Jurnal Bimbingan Konseling Islam, 11(1), 18-35. http://dx.doi.org/10.21043/kr.v11i1.7705

Melani, P. (2021). Peran kiyai dalam pembinaan akhlak santri di pondok pesantren Miftahul Huda 790 Kotabumi Lampung Utara. [Doctoral thesis, UIN Raden 
Salim, Dillah \& Susilowati | Islamic Boarding School Response to the Impact of COVID-19 in Maintaining the Pesantren Values

Intan Lampung]. Indonesia.

Murtadlo, M. (2020). Pembelajaran daring pada masa pandemi covid-19 di lingkungan pesantren. OSF Preprints.

Muspawi, M., \& Vahlepi, S. (2021). Motivation analysis of students selecting alkinanah jambi islamic boarding school as an arabic learning institution. International Journal of Islamic Education, Research and Multiculturalism, 3(2), 79-91. https:// doi.org/10.47006/ijierm.v3i2.54

Mustakim, M. (2021). Learning strategies at pesantren during the COVID-19 pandemic. In D. K. (UMM Malang) (Ed.). Book chapter (pp. 358-366). Malang: Bildung.

Putro, A. A. Y., \& Suryono, Y. (2019, November). New tradition of pesantren in character education. In Journal of Physics: Conference Series, 1254(1), 012002. https://doi.org/10.1088/1742-6596/1254/1/012002

Rahawarin, Z. A. (2019). Pesantren as the basis of development of political ideology in the digital era. Dinamika Ilmu: Jurnal Pendidikan, 19(2), 363-375. https://doi.org/10.21093/di.v19i2.3917

Rijali, A. (2018). Analisis data kualitatif. Alhadharah: Jurnal Ilmu Dakwah, 17(3), 8195. https://dx.doi.org/10.18592/alhadharah.v17i33.2374

Rukajat, A. (2018). Pendekatan penelitian kualitatif (qualitative research approach). Yogyakarta: Deepublish.

Salim, A. (2012). Peningkatan kompetensi peserta didik madrasah melalui pendidikan karakter berbasis pesantren. Cendekia: Jurnal Kependidikan Dan Kemasyarakatan, 10(2), 167. https:// doi.org/10.21154/cendekia.v10i2.409

Suud, F. M., Chaer, M. T., \& Setiawan, W. (2020). Implementation educational psychology theories at traditional boarding school in Aceh. Journal of Critical Reviews, 7(9), 371-377.

Syafe'i, I. (2017). Pondok pesantren: Lembaga pendidikan pembentukan karakter. Al-Tadzkiyyah: Jurnal Pendidikan Islam, 8(1), 61. https:// doi.org/10.24042/atjpi.v8i1.2097

Syah, R. H. (2020). Dampak COVID-19 pada pendidikan di Indonesia: Sekolah, keterampilan, dan proses pembelajaran. SALAM: Jurnal Sosial Dan Budaya Syar-I, 7(5). https:// doi.org/10.15408/sjsbs.v7i5.15314

Wahyono, I. (2019). Strategi kiai dalam mensukseskan pembelajaran nahwu dan 
Salim, Dillah \& Susilowati | Islamic Boarding School Response to the Impact of COVID-19 in Maintaining the Pesantren Values

shorof di pondok pesantren Al-Bidayah Tegalbesar Kaliwates Jember. Tarbiyatuna: Kajian Pendidikan Islam, 3(2), 106. https://doi.org/10.29062/tarbiyatuna.v3i2.262

Zamhari, A., \& Rahmayanti, I. (2021). The response and negotiation of pesantren in maintaining the values of pesantren during the Covid-19 pandemic: A case study of Pondok Pesantren Darussunnah Hadith. Jurnal Iqra': Kajian Ilmu Pendidikan, 6(1), 125-139. https:// doi.org/10.25217/ji.v6i1.1397 